[Agr. Biol. Chem., Vol. 32, No. 7, p. 873 878, 1968]

\title{
Production of Fluorescent Compounds from Guanine by Microorganisms
}

\author{
By Isao Takeda and Shiro Hayakawa \\ Research Laboratory of Asahi Chemical Industry Co., Ltd., \\ Tokyo \\ Received December 11, 1967
}

\begin{abstract}
One species of hydrocarbon utilizing bacteria was isolated from soil. This strain was named as Achromobacter petrophilum No. 4017. This bacterial species utilizes normal hydrocarbons with carbon chains of $n \mathrm{C}_{10}$ to $n \mathrm{C}_{18}$, but does not utilize glucose or other carbohydrates. Achromobacter petrophilum forms small amounts of green-yellow, green-blue and violet fluorescent compounds in the medium containing $n$-hexadecane $\left(n \mathrm{C}_{16}\right)$ as a carbon source. The mutant strain, No. 4510, which requires hypoxanthine and thiamine for growth, was obtained from Achromobacter petrophilum No. 4017 by ultraviolet irradiation and formed considerable amounts of green-yellow fluorescent compound by the addition of guanine to the $n$-hexadecane medium. This fluorescent compound was crystallized from culture broth.
\end{abstract}

In the previous papers, ${ }^{1 \sim 81}$ assimilation of hydrocarbons by yeast and bacteria has been reported by authors. The present paper will describe the accumulation of fluorescent compounds in the medium containing hydrocarbon by a mutant strain of Achromobacter isolated from soil. This strain requires hypoxanthine and thiamine for growth. Substitution of guanine or xanthine for hypoxanthine does not support growth. This mutant is a purine auxotroph and lacks $5^{\prime}$-guanylic acid reductase. The addition of guanine to the culture medium is necessary for the formation of the green-

1) I. Takeda, T. Iguchi, T. Kawamura, S. Horiguchi, S. Hayakawa and S. Senoh, Agr. Biol. Chem., 29, 796 (1965).

2) T. Iguchi, I. Takeda and S. Senoh, ibid., 1, 29 589 (1965)

3) M. Mizuno, Y. Shimojima, T. Iguchi, I. Takeda and S. Senoh, ibid., 30, 506 (1966).

4) T. Iguchi, S. Hayakawa and I. Takeda, J. Agr. Chem. Soc. Japan, 40, 26 (1966).

5) T. Iguchi and I. Takeda, Agr. Biol. Chem,, 30, 709 (1966)

6) T. Iguchi, T. Watanabe and I. Takeda, ibid., 31, 569 (1967).

7) T. Iguchi, T. Watanabe and I. Takeda, ibid. 31, 574 (1967)

8) T. Iguchi, R. Kodaira and I. Takeda, ibid., $\mathbf{3 1}$ 885 (1967). yellow fluorescent compound.

\section{EXPERIMENTAL}

1) Materials. All hydrocarbons were purchased from Tokyo Kasei Chemicals with the exception of $n$-pentadecane obtained from Kanto Koatsu Chemicals. They were above $95 \%$ in purity and used without further purification. "Avicell" (Asahi Chemical Co., over $100 \mathrm{mesh}$ ) was used as cellulose powder for chromatography. DEAE-cellulose was purchased from Brown Co., Berlin.

2) Microorganism. Strain No. 4017 was isolated from soil on the following medium containing $1.5 \%$ agar (Wako Pharm. Co.). The medium was as follows; light oil or kerosene $30 \mathrm{ml},\left(\mathrm{NH}_{4}\right)_{2} \mathrm{SO}_{4} 1.0 \mathrm{~g}$, $\mathrm{NH}_{4} \mathrm{NO}_{3} 1.0 \mathrm{~g}, \mathrm{KH}_{2} \mathrm{PO}_{4} 2.0 \mathrm{~g}, \mathrm{NaHPO}_{4} 2.0 \mathrm{~g}, \mathrm{MgSO}_{4}$. $7 \mathrm{H}_{2} \mathrm{O} \quad 1.0 \mathrm{~g}, \quad \mathrm{FeSO}_{4} \cdot 7 \mathrm{H}_{2} \mathrm{O} \quad 0.005 \mathrm{~g}, \quad \mathrm{MnSO}_{4} \cdot 4 \mathrm{H}_{2} \mathrm{O}$ $0.005 \mathrm{~g}, \mathrm{ZnSO}_{4} \cdot 7 \mathrm{H}_{2} \mathrm{O} 0.005 \mathrm{~g}$, yeast extract (Difco) $1.0 \mathrm{~g}$ and $\mathrm{H}_{2} \mathrm{O} 1,000 \mathrm{ml}$. pH was adjusted 7.0 with $1 \mathrm{~N} \mathrm{KOH}$.

3) Mutation. The minimal medium consisted of $n$-hexadecane $10 \mathrm{ml}, \mathrm{KH}_{2} \mathrm{PO}_{4} 3.0 \mathrm{~g}, \mathrm{~K}_{2} \mathrm{HPO}_{4} 7.0 \mathrm{~g}$, $\left(\mathrm{NH}_{4}\right)_{2} \mathrm{SO}_{4} 1.0 \mathrm{~g}, \mathrm{MgSO}_{4} \cdot 7 \mathrm{H}_{2} \mathrm{O} 0.2 \mathrm{~g}$, Na-citrate $0.5 \mathrm{~g}$ per 1 liter. Strain No. 4017 can grow in this minimal medium at $30^{\circ} \mathrm{C}$. The cells were centrifuged and resuspended in the same medium. Ten $\mathrm{ml}$ of cell suspension $\left(2.8 \times 10^{8}\right.$ cells per $\left.\mathrm{ml}\right)$ was placed in plate 
Table I IdENTIfication of Strain No. 4017

Morphologically;

Gelatin stab;

Agar colonies;

Bouillon culture;

Broth containing peptone;

Potato-dextrose agar;

Litmus milk;

Indole;

Hydrogen sulfide;

Production of nitrite from nitrate;

Acids or gas produced from carbohydrate media;

Ammonium produced from peptone;

Ammonium chloride serves as a source of nitrogen, while urea is not utilized.

Positive after 7 days.
Rods, 0.7 to 0.9 by 0.8 to $1.6 \mu$, occurring in single and pairs. Normally not encapsulated, non-motile and gram negative.

Crateriform liquefaction.

Circular, small, smooth, entire, glistening, slightly raised, whitish with no pigment.

Moderate growth and the cells precipitate at the bottom. No characteristic odor.

Moderate growth, a pellicle is formed and cells precipitate at the bottom.

The colonies are circular, small, smooth entire glistening, slightly raised, whitish with no pigment.

Changed to alkaline after 5 days. There is no peptonization.

Not produced.

Not produced.

No.

Positive. and exposed to ultraviolet irradiation for 80 seconds (National Electric $15 \mathrm{~W}$ germicidal lamp) at a distance of $45 \mathrm{~cm}$. After irradiation, the population density was approximately $2 \times 10^{5}$ viable cells per $\mathrm{ml}$. The irradiated cells were resuspended in the minimal medium and cultured for $5 \mathrm{hr}$ at $30^{\circ} \mathrm{C}$. 500 unit per $\mathrm{ml}$ of penicillin $\mathrm{G}$ ( $\mathrm{T} \bar{o} y \bar{o}$ Jozo Co.) was added in accordance with Lederberg's method. ${ }^{9}$ The survivors were aerobically incubated at $30^{\circ} \mathrm{C}$ in the medium composed of the minimal medium plus vitamin free casamino acids (Difco) $2.0 \mathrm{~g}$, hypoxanthine $20 \mathrm{mg}$, uracil $20 \mathrm{mg}$, tryptophan $10 \mathrm{mg}$, cystine $10 \mathrm{mg}$, thiamine $500 \mu \mathrm{g}$, riboflavin $500 \mu \mathrm{g}$, para-aminobenzoic acid $20 \mu \mathrm{g}$, folic acid $10 \mu \mathrm{g}$, inositol $1,000 \mu \mathrm{g}$ and biotin $5 \mu \mathrm{g}$ per 1 liter $\mathrm{H}_{2} \mathrm{O}$. When the population reached $4 \times 10^{8}$ cells per $\mathrm{ml}$, the cells were collected. The penicillin treatment was repeated four times by the method of Iguchi, Watanabe and Takeda.6)

4) Analytical methods. The green-yellow, greenblue and violet fluorescent compounds were determined as follow. The definite amounts of the culture filtrate were paperchromatographed. The bands corresponding to the green-yellow, green-blue and violet fluorescence were eluted with hot water and the eluates

9) J. Lederberg and E. M. Lederberg, J. Bacteriol., 63, 399 (1952). were assayed spectrophotometrically at 400,400 and $340 \mathrm{~m} \mu$ respectively.

\section{RESULTS AND DISCUSSION}

Table I shows the properties of strain No. 4017. This strain was identified as Achromobacter species according to the Bergey's Mannual of Determinative Bacteriology, 7th Edition, and named Achromobacter petrophilum No. 4017.

Achromobacter petrophilum was inoculated in the following medium; $n$-hexadecane $50 \mathrm{ml}$, $\mathrm{KH}_{2} \mathrm{PO}_{4} 1.0 \mathrm{~g}, \mathrm{MgSO}_{4} \cdot 7 \mathrm{H}_{2} \mathrm{O} 0.5 \mathrm{~g}$, yeast extract (Difco) $10.0 \mathrm{~g},\left(\mathrm{NH}_{4}\right)_{2} \mathrm{SO}_{4} 4.0 \mathrm{~g}$ and $\mathrm{CaCO}_{3}$ (precipitate) $2.0 \mathrm{~g}$ in 1 liter of water at $\mathrm{pH} 6.8$ to 7.0 . The bacteria were cultured in $50 \mathrm{ml}$ of the sterilized medium at $30^{\circ} \mathrm{C}$ for 4 days in $500 \mathrm{ml}$ shaking flasks. After 4 days incubation, small amounts of green-yellow, green-blue and violet fluorescent compounds were accumulated in culture broth. The paperchromatograms of the culture broth are shown in Fig. 1.

Achromobacter petrophilum No. 4017 was treat- 


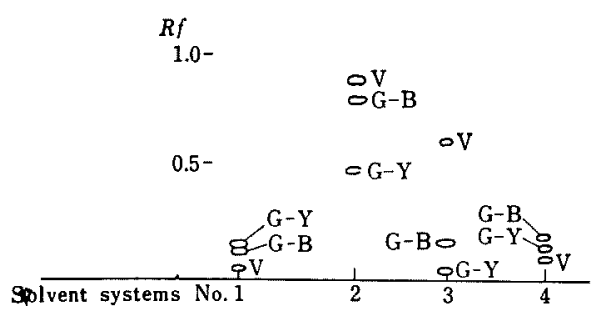

Fig. 1. Paperchromatograms of Fluorescent Compounds in Cultural Broth.

No. 1: Butanol-acetic acid-water $(4: 1: 5)$

No. 2: Water saturated with benzylalcohol

No. 3: $3 \%$ ammoniumchloride

No. 4: Butanol-ethanol-water (10:3:7)

G-Y; Green-yellow fluorescence

G-B; Green-blue fluorescence

$\mathrm{V}$; Violet fluorscence

ed by ultraviolet irradiation and penicillin. The mutants obtained by the above mentioned treatments required a variety of growth factors including amino acids, purines and vitamins. Of these mutants, a strain that produced large amounts of the green-yellow and green-blue fluorescent compounds than the original strain in the culture medium described as above was

TABLE II. THE GROWTH OF Achromobacter petrophilum No. 4510 IN THE MINIMAL MEDIUM SupPlemented With PURINe Bases

Media

Minimal medium ${ }^{1 /}$

plus Xanthine

" Guanine

"Hypoxanthine

"Hypoxanthine, Xanthine

"Hypoxanthine, Guanine +

" Adenine

Minimal medium ${ }^{2}$ plus Hypoxanthine

Minimal medium ${ }^{11}$ is as follows: $n$-hexadecane $5.0 \mathrm{ml}, \mathrm{KH}_{2} \mathrm{PO}_{4} 3.0 \mathrm{~g}, \mathrm{~K}_{2} \mathrm{HPO}_{4} 7.0 \mathrm{~g},\left(\mathrm{NH}_{4}\right)_{2} \mathrm{SO}_{4}$ 1.0, $\mathrm{MgSO}_{4} \cdot 7 \mathrm{H}_{2} \mathrm{O} 0.2 \mathrm{~g}$, Na-citrate $0.5 \mathrm{~g}$, casamino ccid $2.0 \mathrm{~g}$, tryptophan $10 \mathrm{mg}$, cystine $10 \mathrm{mg}$, thiamine $500 \mu \mathrm{g}$, para-aminobenzoic acid $20 \mu \mathrm{g}$, folic acid $10 \mu \mathrm{g}$, inositol $1,000 \mu \mathrm{g}$, riboflavin $500 \mu \mathrm{g}$ and biotin $5 \mu \mathrm{g}$ per 1 liter $\mathrm{H}_{2} \mathrm{O}$.

Minimal medium ${ }^{2}$ : Thiamine is omitted from minimal medium ${ }^{11}$. Purine bases were used at the concentration of $1 \mathrm{mg}$ per 1 liter.

$*+=$ growth, $0=$ no growth selected for further study. This strain, Achromobacter petrophilum No. 4510 , is a purine auxotroph and lacks $5^{\prime}$-guanylic acid reductase, and requires thiamine for growth (Table II).

The mutant strain No. 4510 has the ability to produce considerable amounts of greenyellow fluorescent compound upon addition of guanine to a medium. Hypoxanthine addition also induces the formation of the fluorescent compound. The addition of xanthine to the culture broth was as effective as guanine for the formation of green-yellow fluorescent compound as shown in Table III. The

TABLE III. RElationship BETWEen THE ADDITION OF PURINE BASES AND THE FORMATION OF THE GREEN-YELLOW FLUORESCENT COMPOUND

$\begin{array}{lcc}\begin{array}{c}\text { Bases } \\ \text { (500 mg/liter) }\end{array} & \begin{array}{c}\text { Green-yellow } \\ \text { fluorescent } \\ \text { compound }\end{array} & \text { Growth* } \\ \text { None } & 0.01 & \text { \# } \\ \text { Guanine-HCI } & 0.10 & \text { Ht } \\ \text { Xanthine } & 0.08 & \text { \# } \\ \text { Hypoxanthine } & 0.04 & \text { 册 } \\ \text { Adenine } & 0.04 & \text { H }\end{array}$

The values mentioned above show the reading at $-\log T$.

* $H$ Heh heavy growth.

The medium is composed of $n$-hexadecane $50.0 \mathrm{ml}$, $\mathrm{KH}_{2} \mathrm{PO}_{4} \mathrm{l} .0 \mathrm{~g}, \mathrm{~K}_{2} \mathrm{HPO}_{4} 1.0 \mathrm{~g}, \mathrm{MgSO}_{4} \cdot 7 \mathrm{H}_{2} \mathrm{O}$ C. $.5 \mathrm{~g}$, yeast extract $6.0 \mathrm{~g},\left(\mathrm{NH}_{4}\right)_{2} \mathrm{SO}_{4} 4.0 \mathrm{~g}$, hypoxanthine $10 \mathrm{mg}$ and sterilized $\mathrm{CaCO}_{3} 20.0 \mathrm{~g}$ per 1 liter at $\mathrm{pH}$ 6.8 to 7.0 . The bacteria were cultured in $500 \mathrm{ml}$ shaking flasks containing $50 \mathrm{ml}$ medium at $30^{\circ} \mathrm{C}$ for 4 days.

Table IV. The Effect of the Guanine ConCENTRATION ON THE FORMATION OF THE Green-yellow Flourescent Compound

$\begin{array}{cc}\begin{array}{c}\text { Guanine-HCl } \\ \text { (mg/liter) }\end{array} & \begin{array}{c}\text { Green-yellow fluorescent } \\ \text { compound }\end{array} \\ 50 & 0.02 \\ 100 & 0.03 \\ 200 & 0.04 \\ 400 & 0.10 \\ 800 & 0.10\end{array}$

The culture medium and other conditions were the same as Table II. 
concentration of guanine on the formation of this fluorescent compound was tested. Table IV shows that the addition of $400 \mathrm{mg}$ of guanine per liter was the most effective. The relationship between the assimilation of hydrocarbons and the formation of the green-yellow fluorescent compound is shown in Table V. Normal

Table V. The Assimilation of HydrocarBONS AND THE FORMATION OF THE GREENYELLOW FLUORESCENT COMPOUND

\begin{tabular}{|c|c|c|}
\hline Carbon source & Growth* & $\begin{array}{c}\text { Fluorescent } \\
\text { compound** }\end{array}$ \\
\hline$n$-Decane & $H$ & \\
\hline$n$-Decanoic acid & 0 & \\
\hline$n$-Undecane & $H$ & \\
\hline$n$-Dodecane & H & + \\
\hline Isododecane & + & \\
\hline$n$-Tridecane & 世 & + \\
\hline$n$-Tetradecane & 册 & + \\
\hline Tetradecene-1 & HA & + \\
\hline$n$-Pentadecane & 世 & + \\
\hline Heptamethylnonane & \pm & \\
\hline$n$-Hexadecane & HWH & + \\
\hline Hexadecene-1 & 册 & + \\
\hline n-Octadecane & H & + \\
\hline Glucose & 0 & \\
\hline Na-Succinate & 0 & \\
\hline Glycerine & 0 & \\
\hline Na-Acetate & H & + \\
\hline
\end{tabular}

All hydrocarbons were used at a concentration of $50.0 \mathrm{ml}$ per liter. The culture media and other conditions were the same as Table III, but $n$-hexadecane was omitted and guanine was added at a concentration of $500 \mathrm{mg}$ per I liter.

* $H$ heavy growth, $0=$ no growth.

** $+=$ formation of the fluorescent compound.

hydrocarbons from tridecane to octadecane showed good growth and good formation of the green-yellow fluorescent compound. Glucose, glycerine and $\mathrm{Na}$-succinate were not assimilated by this mutant, but $\mathrm{Na}$-acetate was utilized as a carbon source. The formation of the green-yellow fluorescent compound was stimulated by the addition of $\mathrm{MgSO}_{4} \cdot 7 \mathrm{H}_{2} \mathrm{O}$ and $\mathrm{CaCO}_{3}$ into the culture broth as shown in Table VI and VII.

Achromobacter petrophilum No. 4510 was cul-
Table VI. The Concentration of $\mathrm{MgSO}_{4}$. $7 \mathrm{H}_{2} \mathrm{O}$ AND THE FORMATION OF THE GREENYELLOW FLUORESCENT COMPOUND

$\begin{array}{cc}\mathrm{MgSO}_{4} \cdot 7 \mathrm{H}_{2} \mathrm{O} & \begin{array}{c}\text { Green-yellow fluorescent } \\ (\mathrm{g} / \text { liter })\end{array} \\ 0 & \text { compound } \\ 0.5 & 0.01 \\ 1.0 & 0.02 \\ 5.0 & 0.06 \\ 10.0 & 0.10 \\ \end{array}$

The media were the same as Table III except for a concentration of $\mathrm{MgSO}_{4} \cdot 7 \mathrm{H}_{2} \mathrm{O}$ and an addition of guanine-HCl $500 \mathrm{mg} / \mathrm{liter}$. The bacteria were cultured in $500 \mathrm{ml}$ shaking flasks containing $50 \mathrm{ml}$ medium at $30^{\circ} \mathrm{C}$ for 4 days.

TABle VII. The Formation OF THE GREenYELLOW FLUORESCENT COMPOUND AND $\mathrm{CaCO}_{3}$

$\begin{array}{cc}\mathrm{CaCO}_{3} & \text { Green-yellow fluorescent } \\ \text { (g/liter) } & \text { compound } \\ 0 & 0 \\ 20 & 0.9\end{array}$

The media and the culture conditions were the same as Table III except for the additions of $400 \mathrm{mg}$ of guanine and of $4.0 \mathrm{~g}$ of $\mathrm{MgSO}_{4} \cdot 7 \mathrm{H}_{2} \mathrm{O}$ per liter.

tured at $30^{\circ} \mathrm{C}$ for 4 days in $50 \mathrm{ml}$ of the sterilized medium described as follows in $500 \mathrm{ml}$ shaking flasks; $n$-hexadecane $50 \mathrm{ml}, \mathrm{KH}_{2} \mathrm{PO}_{4}$ $1.0 \mathrm{~g}, \mathrm{~K}_{2} \mathrm{HPO}_{4} 1.0 \mathrm{~g}, \mathrm{MgSO}_{4} \cdot 7 \mathrm{H}_{2} \mathrm{O} 4.0 \mathrm{~g}$, yeast extract $6.0 \mathrm{~g},\left(\mathrm{NH}_{4}\right)_{2} \mathrm{SO}_{4} 4.0 \mathrm{~g}$, Hypoxanthine $10 \mathrm{mg}$, guanine- $\mathrm{HCl} 500 \mathrm{mg}$, and sterilized $\mathrm{CaCO}_{3} 20 \mathrm{~g}$ per 1 liter $\mathrm{H}_{2} \mathrm{O}$ at $\mathrm{pH} 6.8$ to 7.0. Ammonium sulfate $(60 \%)$ was added to 1 liter of the culture broth. The cells and the coagulated proteins were removed by filtration. Phenol $(30 \mathrm{ml})$ was added to the filtrate $(900 \mathrm{ml})$ and all the fluorescent compounds including the green-yellow, green-blue and violet fluorescent compounds were extracted according to the method of Crammer. ${ }^{10)}$ Ether $(60 \mathrm{ml})$ and water $(15 \mathrm{ml})$ were mixed perfectly with the phenol extracts and the aqueous layer was passed throgh a column of powdered cellulose (Avicell) equilibrated with water saturated with benzylalcohol. The fluorescent compounds

10) J. L. Crammer, Nature, 161, 349 (1948). 
were eluted from the column by water saturated with benzylalcohol. The aqueous layer, after removal of benzylalcohol by the addition of a small volume of ether, was adsorbed on a DEAE-cellulose column washed with $0.01 \mathrm{~N}$ $\mathrm{HCl}$ solution. The green-yellow fluorescent compound was eluted with $0.05 \mathrm{~N} \mathrm{HCl}$ solution. The eluate was adsorbed to $300 \mathrm{mg}$ of Norit A washed with $0.1 \mathrm{NHCl}$ solution. Norit A was washed with acidic solution ( $\mathrm{pH} 5)$ of $\mathrm{HCl}$. The green-yellow fluorescent compound was eluted from Norit A with $60 \%$ ethanol solution containing $1 \% \mathrm{NH}_{4} \mathrm{OH}$. The eluate was evaporated in vacuo to $5 \mathrm{ml}$ and $0.5 \mathrm{ml}$ of glacial acetic acid was added following the method of Forrest and McNutt. ${ }^{11}$ The precipitate was collected by centrifugation and discarded. The supernatant, on addition of methanol (5 $\mathrm{ml}$ ), yielded pale yellow crystals. In this way, $3 \mathrm{mg}$ of crystal were obtained from 1 liter of culture broth. The acicular crystals (Fig. 2) were reddish-yellow.

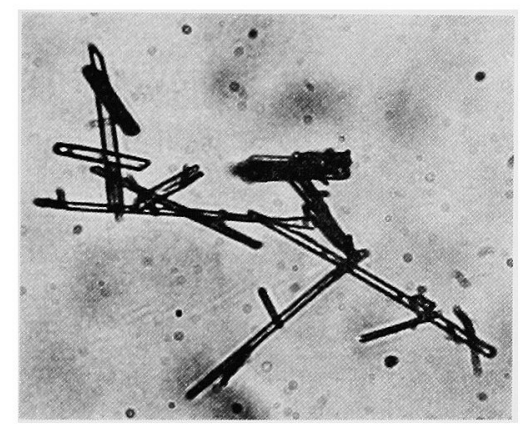

FIG. 2. Crystals of Green-yellow Fluorescent Compound.

The melting point of the crystal was found to be 291 to $295^{\circ} \mathrm{C}$ (decomp.). This compound showed no "folic acid" activity in the bioassay for Streptococcus faecalis $\mathrm{R}^{121}$ or Lactobacillus casei. $^{13)}$ The ultraviolet absorption spectra of this compound are shown in Fig. 3. The peaks

11) H. S. Forrest and W. S. McNutt, J. Am. Chem. Soc., 80, 739 (1958).

12) E. E. Snell, E. Kitay and W.S. McNutt, $J$. Biol. Chem., 175, 473 (1948).

13) B. C. Johnson, ibid., 163, 255 (1946).

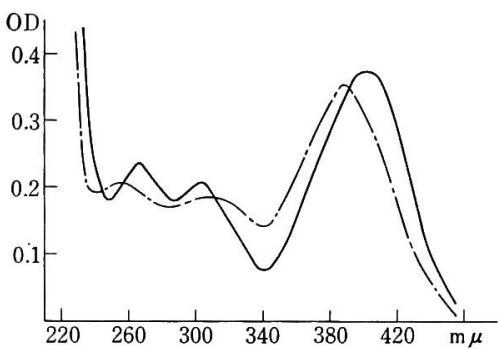

FIG. 3. Ultraviolet Spectrum of Green-yellow Fluorescent Compound.

$0.1 \mathrm{~N} \mathrm{NaOH}$ solution

$0.1 \mathrm{~N} \mathrm{HCl}$ solution

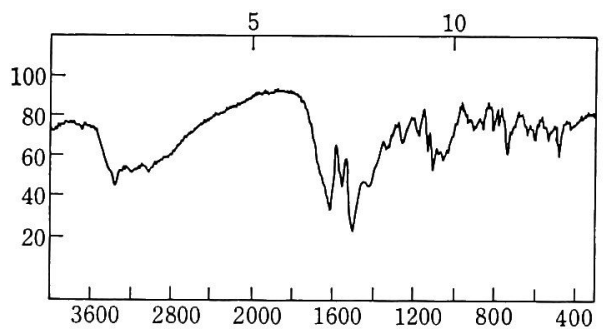

Fig. 4. Infrared Spectrum of the Green-yellow Fluorescent Compound.

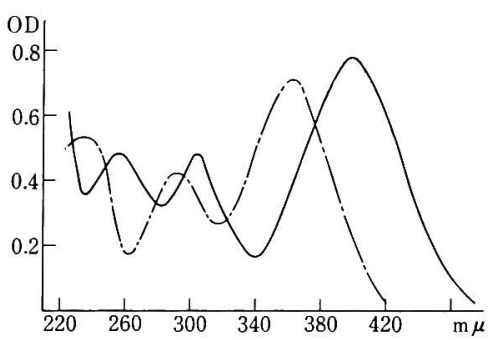

FIG. 5. The Ultraviolet Spectrum of the Greenblue Fluorescent Compound.

$0.1 \mathrm{~N} \mathrm{NaOH}$ solution
$0.1 \mathrm{~N} \mathrm{HCl}$ solution

at $305 \mathrm{~m} \mu$ in $0.1 \mathrm{~N} \mathrm{NaOH}$ solution and at $310 \mathrm{~m} \mu$ in $0.1 \mathrm{~N} \mathrm{HCl}$ solution reveal a difference from the spectra obtained with pteridine derivatives. Fig. 4 shows the infrared absorption spectrum of the green-yellow fluorescent compound. As shown in Fig. 5, a green-blue fluorescent compound shows an ultraviolet spectrum similar to that of a green-yellow fluorescent compound. 
These green-yellow and green-blue fluorescent compounds are derived from guanine as shown in the preceding paragraphs. However, when $8-{ }^{14} \mathrm{C}$-guanine $(10 \mu \mathrm{C})$ was added to $10 \mathrm{ml}$ of the culture medium in $24 \mathrm{hr}$ after inoculation and incubated for 4 days, no label was incorporated into these green-yellow and greenblue fluorescent compounds. Thus, carbon 8 of guanine is not involved in the formation of these compounds. It has previously been reported that it is not involved in the formation of pteridine compounds from guanine. ${ }^{14-17)}$ The green-yellow fluorescent compound seems

14) W. S. McNutt, J. Biol. Chem., 219, 365 (1956).

15) Ziegler-Gunder, $H$. Simon and $A$. Wacker, $Z$. Naturforsch., 11a, 82 (1956).

16) F. Weygand, H. Simon, G. Dahms, M. Waldschmidt, H. J. Schliep and H. Wacker, Angew. Chem., 73, 402 (1961).

17) B. Levenburg and D. K. Kaczmarek, Biochim. Biophys. Acta, 117, 272 (1966). to be different from pteridine derivatives produced by Eremothecium ashbyii, ${ }^{181}$ Mycobacterium smegmatis, ${ }^{191}$ and Aspergillus oryzae. ${ }^{201}$ The structure and physiological role of these compounds have yet to be elucidated.

Acknowledgements. The authors wish to express their thanks to Dr. A. Suzuki who is Director of this laboratory for his interest and encouragement during the course of this work. Infrared spectrum was taken by Dr. M. Nagumo of this laboratory, to whom the authors express their sincere gratitude. We also wish to express appreciation to Dr. L. Corman, Tufts University, School of Medicine, U.S.A., for his criticism of the manuscript.

18) T. Masuda, Pharm. Bull. Japan, 4, 71 (1956).

19) M. Goto, K. Kobayashi, H. Sato and F. Korte, Ber., 689, 221 (1965).

20) Y. Kaneko, Agr. Biol. Chem., 29, 965 (1965). 